Tom LXXV - 2015

\begin{tabular}{llllllll}
\hline $\mathrm{P}$ & $\mathrm{O}$ & $\mathrm{L}$ & $\mathrm{E}$ & $\mathrm{M}$ & $\mathrm{I}$ & $\mathrm{K}$ & $\mathrm{A}$
\end{tabular}

RAFAモ MATERA

Katedra Historii Myśli Ekonomicznej i Historii Gospodarczej

Wydział Ekonomiczno-Socjologiczny Uniwersytetu Łódzkiego

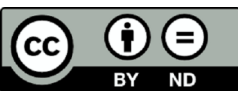

\title{
KILKA UWAG NA TEMAT MIEJSCA BADAŃ ILOŚCIOWYCH W POLSKIEJ HISTORII GOSPODARCZEJ. STAN I PERSPEKTYWY
}

$\mathrm{Z}$ dużym zainteresowaniem, ale też z równie dużym krytycyzmem przeczytałem artykuł zatytułowany Miejsce badań kwantytatywnych we wspótczesnej historiografii polskiej, który ukazał się w 2013 r. w tomie 73 „Roczników Dziejów Społecznych i Gospodarczych”. Opublikowało go dwóch rozwojowych badaczy z Instytutu Historii i Nauk Politycznych Uniwersytetu w Białymstoku - Piotr Guzowski i Radosław Poniat ${ }^{1}$. Tytuł publikacji zapowiadał realizację wielkiego projektu, czy choćby próbę szerszego spojrzenia na wskazany problem, faktycznie jest on zaś tylko przyczynkiem do oceny stanu badań w polskiej historii gospodarczej i demografii historycznej, czego przecież nie można utożsamiać w znaczącej części z historiografią polską. Należy przyznać, że autorzy uczciwie zaznaczyli to już na początku artykułu (ale jednak szeroki, ambitny i przyciagajacy tytuł pozostawili niezmieniony).

Badacze postawili odważną tezę, że mimo rozkwitu badań kwantytatywnych w zachodniej historiografii artykuły o takim charakterze przestały się ukazywać w czasopismach historycznych o charakterze ogólnym, a przez to sa one nieznane historykom (w podtekście: zwłaszcza polskim). Należałoby się zgodzić, że faktycznie to ekonomiści znacznie lepiej przyswajają ilościowe podejście w analizie naukowej. Wydaje się to naturalne, nie blokuje przecież jednak chętnym historykom możliwości zgłębiania i wykorzystywania zaawansowanych metod ilościowych. Nie jest też dziś dobrą wymówką twierdzenie, że artykuły tego typu sa „ukrywane” w innego rodzaju czasopismach, skoro przeglądarki baz artykułów są dla naukowców otwarte permanentnie on-line.

${ }^{1}$ P. Guzowski, R. Poniat, Miejsce badań kwantytatywnych we wspótczesnej historiografii polskiej, RDSG, t. 73, 2013, s. 243-255. 
Po uważnej lekturze artykułu naszła mnie ponadto poważna wątpliwość, czy aby na pewno historia powinna raptownie (czy nawet stopniowo) zmieniać swoje podejście do metod i przeobrażać się w naukę ścisła. Dla wszystkich historyków bez wyjątku podstawowym zadaniem powinno być nie tylko przedstawienie $\mathrm{w}$ miarę pełnego obrazu, ale też wyjaśnianie zależności i rozbieżności, przyczyn sukcesu i klęski, dostrzegania prosperity i kryzysu, identyfikacji centrum i peryferii. Należałoby znajdować ponadto argumenty na rzecz celu historii jako nauki, pojmowanego $\mathrm{w}$ ten sposób, że może ona jednak dostarczać pewnych uogólnień, wyjaśniać jakieś zjawiska, że wbrew stanowisku Lwa Tołstoja jednak może odkrywać przyczyny, a przynajmniej pomagać w ich odkrywaniu. Tołstoj pisał bowiem, że historia ukazuje tylko pozbawione wyrazu następstwo niewyjaśnionych zdarzeń, przez co nie odkrywa przyczyn. Przekonywał, że nie operuje ona własnymi koncepcjami. Zdaniem Isaiaha Berlina - dogłębnego krytyka myśli Tołstoja - unicestwiłoby to historię jako taką ${ }^{2}$. Historycy winni wspólnie pracować przeciwko ziszczeniu się takiego katastroficznego scenariusza, ale niekoniecznie musi się to stać za pomocą metod ilościowych.

W przypadku wykorzystania kwantytatywnych rozwiąań bardziej znane mi sa dylematy historyka gospodarczego niźli „historyka ogólnego". Historia gospodarcza ma bowiem obowiązek opierać się na dwóch filarach: historii i ekonomii, ale to nie znaczy, że każdy historyk gospodarczy musi sprostać wysokim wymaganiom metodologicznym obu dyscyplin. Wybitny ekonomista, a z wykształcenia historyk, orędownik teorii racjonalnych oczekiwań i laureat Nagrody Nobla z 1995 r. Robert E. Lucas jr. mówił, że „tylko niektórzy ekonomiści powinni być kompetentnymi historykami, inni kompetentnymi matematykami, a jeszcze inni kompetentnymi socjologami itd. Trzeba pamiętać, że nie ma ani potrzeby, ani możliwości, by być dobrym we wszystkim”3. Jakkolwiek uważam, że „historycy ogólni” (albo inaczej: bez określonej trwałej specjalizacji) wcale nie unikaja metod ilościowych li tylko ze względu na braki w wykształceniu matematycznym, ale raczej z prostego powodu - braku przekonania do tego typu badań. Zresztą ten brak zaufania do metod ilościowych dotyczy również części ekonomistów (choć na pewno w mniejszym stopniu niż historyków).

${ }^{2}$ I. Berlin, Jeż i lis. Esej o pojmowaniu historii u Tołstoja, wstęp J. Brodski, tłum. A. Konarek, H. Krzeczkowski, K. Tarnowska, Warszawa 1993, s. 63.

${ }^{3}$ Wywiad z Lucasem w: B. Snowdon, H.R. Vane, Rozmowy z wybitnymi ekonomistami, tłum. M.A. Dąbrowski, P. Kawa, Warszawa 2003, s. 201. 
Zdaniem części środowiska historyków gospodarczych (również zachodniego) historia gospodarcza będzie mogła wnosić wartość dodana do nauki, jeśli tylko znajdzie trwałe połączenie między tradycyjna historia, preferująca podejście idiograficzne (które nie abstrahuje od selekcji i zestawienia faktów), a współczesna ekonomia, która dąży do tworzenia modeli. Janina Godłów-Legiędź zastanawia się, jakie towarzyszą temu zagrożenia: „Jednakże zarówno na gruncie historii, jak i ekonomii, istnieje potrzeba praktykowania obu podejść. Problemy metodologiczne tych nauk związane sa z nieuniknionym balansowaniem między szczegółowościa analizy a dążeniem do syntezy w postaci formułowania praw ogólnych. Rzeczywistość jest nierozdzielnym splotem różnorodnych faktów i wartości, ale jeżeli ograniczymy się jedynie do rejestrowania tej różnorodności, brakować będzie wniosków i drogowskazów"4.

Przed bezkrytycznym zaufaniem do metod kwantytatywnych przestrzegał również jeden z najwybitniejszych metodologów ekonomii Mark Blaug 5 - który apelował, by jej nauczanie nie sprowadzało się wyłącznie do przyswajania określonego warsztatu pojęciowego czy quasi-matematycznych idei. Według niego: „Właściwym podejściem do nauczania ekonomii jest oparcie się na metodologii i ujęciu historycznym" ${ }^{\prime}$. O to też powinni walczyć historycy gospodarczy. Aby obronić tę tezę, Blaug odniósł się m.in. do jednej z uwag Miltona Friedmana, który, w przeciwieństwie do wielu współczesnych mu badaczy, weryfikując moc naukową hipotez ekonomicznych, odwoływał się raczej do historii niż do regresji ${ }^{7}$. Problemem współczesnej ekonomii (również historii gospodarczej) jest fakt, że proporcje między obu podejściami zostały poważnie zachwiane. Badacze, którzy znaleźli się w orbicie rygoryzmu, zdominowali resztę. A może to jednak tradycjonaliści dali się zdominować? Podejmowanie badań na styku ekonomii, polityki i socjologii wiąże się z obrona podejścia historycznego i jest swoista ucieczką od rygoryzmu (przynajmniej w przypadku części badań).

Trzeba w tym miejscu dodać, że wielu badaczy nie podejmuje ryzyka łączenia badań w kilku dyscyplinach (w tym ekonomii i historii)

${ }^{4}$ J. Godłów-Legiędź, Wspótczesna ekonomia. Ku nowemu paradygmatowi?, Warszawa 2010, s. 16.

${ }^{5}$ Blaug jest autorem swoistej Biblii metodologicznej dla ekonomistów; zob. M. Blaug, Metodologia ekonomii, tłum. B. Czarny, A. Molisak, Warszawa 1995. Polecam też studiowanie jego innego wielkiego dzieła: tenże, Teoria ekonomii. Ujęcie retrospektywne, tłum. I. Budzyńska, Warszawa 2000.

${ }^{6}$ B. Snowdon, H.R. Vane, dz. cyt., s. 432.

${ }^{7}$ Tamże, s. 434. 
ze względu na obawy o zarzut wymieszania metodologii, a przecież zawsze korzystanie $\mathrm{z}$ dorobku kilku dyscyplin niesie takie ryzyko. Warto w tym miejscu przypomnieć, że otwartość w doborze metod promowali nie tylko wybitni ekonomiści (tak jak Alfred Marshall ${ }^{8}$ czy Keynesowie: John Neville i John Maynard), zalecając użycie takich technik, które byłyby najbardziej odpowiednie z punktu widzenia realizacji określonych celów naukowych. Apelowali o to również przedstawiciele innych nauk, w tym dyscyplin typowo humanistycznych. Filozof Lew Szestow pisał, że „główne zadanie nauki, jak i etyki, zawiera się w tym, aby dać ludziom mocna podstawę w życiu, nauczyć ich rozróżniać to, co jest, od tego, czego nie ma, i to, co można, od tego, czego nie można. Droga do tego to mimo wszystko sprawa drugorzędna, a na pewno nie tak ważna, aby zapominać o podstawowym celu" .

Kontrowersyjny (wyłącznie ze względu na postawione tezy i niektóre oceny, ale nie ze względu na zawartość merytoryczna) tekst Guzowskiego i Poniata dobrze wpisuje się w polski wkład do dyskusji historyków gospodarczych na temat możliwości publikacji w czasopismach zachodnich oraz wykorzystania w nich właśnie metod ilościowych. Zanim przystapi się jednak do rozeznania „rynku krajowego” polecam zwłaszcza artykuł autorstwa Gianfranco Di Vaio i Jacoba Weisdorfa, z serii „Discussion Papers” (nr 9/11 ${ }^{10}$ ) wydawanej przez Katedrę Ekonomii Uniwersytetu Kopenhaskiego, pt. Ranking Economic History Journals. A Citation-Based Impact - Adjusted Analysis, w którym autorzy porównali 12 czasopism o zasięgu międzynarodowym z dziedziny historii gospodarczej. Ranking periodyków uwzględniał standardowa analizę cytowań tylko za rok 2007. Jednak to, co jest szczególnie wartościowe $\mathrm{w}$ publikacji, to próba porównania liczących się czasopism $\mathrm{z}$ historii gospodarczej z wiodaccymi pismami naukowymi z ekonomii. Autorzy czynią to, by zmierzyć wzajemny wpływ obu dyscyplin. Badacze z Rzymu i Kopenhagi potwierdzili, że to sprofilowane czasopisma $\mathrm{z}$ historii gospodarczej mają zdecydowanie największy wpływ na historyków gospodarczych, a nie najlepsze czasopisma ekonomiczne,

\footnotetext{
${ }^{8}$ Stanowisko Marshalla wobec doboru metod przez ekonomistów było bardzo otwarte. Pisał m.in., że powinni oni korzystać z każdego źródła, które pomagałoby im odkrywać rzeczywiste różnice badanych zjawisk; zob. J. Dzionek-Kozłowska, System ekonomiczno-spoteczny Alfreda Marshalla, Warszawa 2007, s. 72.

${ }^{9}$ L. Szestow, Dostojewski i Nietzsche. Filozofia tragedii, tłum. C. Wodziński, Warszawa 1987, s. 203.

${ }^{10}$ G. Di Vaio, J. Weisdorf, Ranking Economic History Journals. A Citation-Based Impact - Adjusted Analysis, „Discussion Papers” 2010, nr 9/11, http://www.econ.ku. dk/english/research/publications/wp/dp_2009/0911.pdf (14 VII 2014).
} 
co oznacza, że historia gospodarcza jest niezależna od ekonomii jako całości. Wychodzi więc na to, że nie tylko jest tak, jak piszą Guzowski i Poniat, iż zawodowi historycy nie znają owoców pracy badaczy z zakresu historii gospodarczej i demografii historycznej (a także ich metod) ${ }^{11}$, ale że historycy gospodarczy ufają i sięgaja głównie po prace ze „swoich branżowych” czasopism, a nie po czyste analizy ekonomiczne czy ogólne dzieła historyczne (w artykule Di Vaio i Weisdorfa nie sa jednak brane pod uwagę ogólne czasopisma historyczne).

Szkoda też, że autorzy artykułu w RDSG nie zapoznali się z trzema rozdziałami monografii z 2011 r. pt. Przeglad badań nad historia gospodarcza $w X X I$ wieku ${ }^{12}$ (w której zreszta jednym $\mathrm{z}$ autorów jest Piotr Guzowski), gdzie również polscy badacze analizowali (także pod katem wykorzystania badań kwantytatywnych) najbardziej uznane na świecie anglojęzyczne periodyki z zakresu historii gospodarczej. Wszystkie one znajdują się na tzw. liście filadelfijskiej (właściwie Journal Citation Report). Należą do nich: „The Economic History Review”, „Journal of Economic History” oraz „Explorations in Economic History”. W monografii charakterystyka tych czołowych pism dokonana została przez pryzmat kilku aspektów: afiliacji publikujaccych tam autorów, podejmowanej tematyki, okresów historycznych, zakresu geograficznego problematyki i stosowanej metodologii. Pozwolić miało to czytelnikowi odnieść te informacje do stanu rodzimej nauki i wyjaśnić brak wśród autorów tam publikujacych specjalistów z Polski. Trzeba podkreślić, że nie wszystkie wnioski z analiz przeprowadzonych przez Kamila Kowalskiego, Andrzeja Pieczewskiego i Adama Bukowskiego były wspólne.

Kowalski po przestudiowaniu „The Economic History Review” pod kątem wykorzystania bardziej zaawansowanych instrumentów statystyki, matematyki czy ekonometrii (przejrzyście zilustrował te trendy za pomocą wykresów) stwierdził, że nie da się potwierdzić tezy o postępującej matematyzacji historii gospodarczej. Według niego bardziej zaawansowane metody matematyczne zostały użyte w mniej niż $20 \%$ artykułach. Pomimo więc, że kliometria wydaje coraz bardziej znaczącym nurtem współczesnej historiografii, wzrost jej znaczenia nie zyskuje potwierdzenia przy charakterystyce artykułów z „The Economic History Review" w pierwszej dekadzie XXI w. ${ }^{13}$

${ }^{11}$ P. Guzowski, R. Poniat, dz. cyt., s. 243.

${ }^{12}$ Przeglad badań nad historia gospodarcza $w$ XXI wieku, red. R. Matera, A. Pieczewski, Łódź 2011.

${ }^{13} \mathrm{~K}$. Kowalski, Nowe trendy $w$ historii gospodarczej. „The Economic History Review" w latach 2001-2009, w: tamże, s. 210. 
Inaczej wyniki badania wyglądały po przestudiowaniu tomów „Journal of Economic History” oraz „Explorations in Economic History”, gdzie faktycznie dominowało podejście kliometryczne. W „Journal of Economic History" tradycyjna historia gospodarcza obecna była w zaledwie kilku syntetycznych opracowaniach o szerszym charakterze czasowym. Narracja odwołująca się do stylu szkoły „Annales” praktycznie nie występowała. Pieczewski pisze, że w środowisku toczy się debata na temat swoistej monokultury metodologicznej panującej w analizowanym czasopiśmie. Podnoszone są postulaty wprowadzenia szerszej „dyskusji historycznej”, w której ważne zmiany i punkty zwrotne w historii powinny być analizowane za pomoca metod nowej ekonomii instytucjonalnej i teorii racjonalnego wyboru ${ }^{14}$.

Również jednostronnie metodologicznie przedstawia się dobór artykułów w „Explorations in Economic History”. Zresztą na oficjalnej stronie internetowej wydawnictwa, w części poświęconej samemu periodykowi, można przeczytać, że szeroko wykorzystuje on narzędzia analizy ekonomicznej w dziedzinie badań nad historia gospodarcza, z uwzględnieniem stosunkowo nowej dziedziny, jaka jest kliometria. „W czasopiśmie tradycyjnie stosowane sa innowacyjne teorie i techniki ilościowe do wieloaspektowej analizy zmian gospodarczych na przestrzeni dziejów, na całym świecie, bez względu na system polityczny czy społeczny. Zamieszczone artykuły zainteresuja ekonomistów, historyków gospodarczych, demografów, geografów i socjologów”15.

Kwestie wykorzystania metod kwantytatywnych przez historyków gospodarczych i historyków biznesu podnosi ponadto ciekawy artykuł trzech fińskich autorów (Jari Eloranty, Jari Ojali, Heli Valtonena) pod prowokacyjnym tytułem: Are Business Historians Quantitatively Illiterate?, który został zaprezentowany w 2008 r., ale bada stan z ostatniej dekady XX stulecia ${ }^{16}$. Badacze nordyccy mierzą w nim, jak często używane sa metody kwantytatywne przez historyków biznesu w dwóch czołowych czasopismach branżowych: „Business History” i „Business

\footnotetext{
${ }^{14}$ A. Pieczewski, Przeglad publicystyki naukowej amerykańskiego Stowarzyszenia Historii Gospodarczej (The Economic History Association), w: tamże, s. 223.

${ }^{15} \mathrm{Ze}$ strony internetowej czasopisma: http://www.journals.elsevier.com/explorations-in-economic-history (14 VII 2014); więcej zob. A. Bukowski, Przeglad publikacji $z$ historii gospodarczej na tamach „Explorations in Economic History” w latach 2001-2010, w: Przeglad badań nad historia gospodarcza..., s. 225-234. Artykuł został również znakomicie zilustrowany różnego typu wykresami.

${ }^{16}$ J. Eloranta, J. Ojala, H. Valtonen, Are Business Historians Quantitatively Illiterate?, referat zaprezentowany na konferencji European Business History Association, Bergen 2008, http://research.jyu.fi/orgevolution/researchpapers/eloranta_ojala_valtonenEBHA08.pdf (14 VII 2014).
} 
History Review”. W konkluzjach zwracaja uwagę, że nawet proste użycie metod ilościowych podnosi możliwości cytowania $\mathrm{w}$ „Business History Review", a bardziej zaawansowane metody ilościowe przedstawiane $\mathrm{w}$ artykułach dają jeszcze większe szanse cytowań w tym periodyku. Takiej zależności autorzy nie dostrzegli w „Business History”, który jest równie solidnie umocowany teoretycznie, ale też bardziej przywiazany do tradycyjnych metod. W każdym razie badacze stwierdzaja, że historycy biznesu nie są analfabetami ilościowymi i korzystaja wystarczająco z owoców międzydyscyplinarnej wymiany. Wprawdzie historia biznesu w Polsce znajduje się jeszcze w powijakach, ale próby przeniesienia doświadczeń dydaktycznych z USA do Polski powoli sa chociaż dyskutowane ${ }^{17}$. Natomiast dla naszych rozważań istotny wniosek jest taki, że podobnie jak w wyspecjalizowanych czasopismach z zakresu historii gospodarczej, tak i w historii biznesu istnieją różne podejścia do metodologii badań i trudno jest jednoznacznie stwierdzić, które $\mathrm{z}$ nich jest dominujace.

Autorzy intrygującego artykułu z RDSG zmierzyli zaawansowanie statystyczne, a szerzej kwantytatywne w czterech ważnych polskich periodykach historycznych: dwóch ogólnych i dwóch branżowych. Nie będę w tym miejscu omawiał tych wyników, ale tym, na co warto zwrócić uwagę, jest fakt, że badacze wydawali się ukontentowani, jeśli tylko znaleźli w przeszukiwanych artykułach jakąkolwiek tabelę czy wykres. Niestety, nie miało to najczęściej wiele wspólnego z wykorzystaniem bardziej zaawansowanej statystyki, nie mówiąc o narzędziach ekonometrycznych.

Muszę przyznać, że z większością wniosków autorów się zgadzam (zwłaszcza wyprowadzanych z prezentowanego badania), ale największy mój sprzeciw budzi jednostronna ocena kondycji historii gospodarczej umieszczona w podsumowaniu artykułu. Guzowski i Poniat wyraźnie preferuja demografię historyczna, mierząc jej potencjał udziałem polskich badaczy na jednym (uznaję, że ważnym) z międzynarodowych kongresów historycznych. Natomiast ocena stanu historii gospodarczej jest bardzo krzywdząca. W artykule przeczytać możemy, że: „Historia gospodarcza przeżywa widoczny kryzys, będący w pewnym sensie wynikiem reakcji środowiska historycznego na instytucjonalne jej faworyzowanie we wczesnej PRL"18. Skutek tego jest m.in. taki, że w podręcznikach

${ }^{17} \mathrm{Na}$ tym polu działa zwłaszcza Mariusz Jastrząb; zob. tenże, Problematyka społecznej odpowiedzialności w nauczaniu historii biznesu w Harvard Business School, „Annales. Etyka w Życiu Gospodarczym” 16, 2013, s. 63-74.

${ }^{18}$ P. Guzowski, R. Poniat, dz. cyt., s. 253. 
historii nie ma ilustracji wykresów i tabel... To jest, delikatnie rzecz ujmując, bardzo uproszczone wytłumaczenie. Czy naprawdę za brak statystycznego podejścia $\mathrm{w}$ najnowszych osiagnięciach polskiej historiografii należy winić historyków gospodarczych? Guzowski i Poniat ponadto dostrzegli załamanie ram instytucjonalnych współpracy środowiska, co skutkuje m.in. tym, że „młode pokolenia adeptów historii preferuja tradycyjna historiografię polityczną i wojskowa, modne badania nad dziejami kultury, mentalnością czy antropologię historyczna" ${ }^{19}$. Nie będę cytował wszystkich nieuzasadnionych zdań, bo można je przeczytać w tomie „Roczników”, ale czuję się w obowiązku zareagować i odpowiednimi argumentami odpowiedzieć na te zarzuty.

Po pierwsze, minęło już ćwierć wieku od upadku komunizmu i blisko pół wieku od czasu, kiedy historia gospodarcza była narzędziem politycznym w naukach ekonomicznych. To wystarczajacy dystans dziejowy, by nie łączyć z tym faktem konsekwencji dla współczesnego środowiska naukowego. Duża grupa historyków gospodarczych zaczęła uprawiać omawiana dyscyplinę już w latach 90. i w nowym milenium, a nawet ci, którzy zaczynali w latach 70. i 80. ubiegłego wieku, nie zostali zindoktrynowani w sposób, w jaki miało to miejsce w latach 50. czy 60.

Po drugie, autorzy artykułu powinni wiedzieć, że środowisko historyków gospodarczych jak mało które mocno się zintegrowało w ostatnich 10 latach. Jest to wynikiem zaangażowania kilku ośrodków naukowych. Organizacji konferencji przyciagającej historyków gospodarczych podjęły się katedry ze Szkoły Głównej Handlowej, Uniwersytetu Łódzkiego, Uniwersytetu Adama Mickiewicza w Poznaniu, a przede wszystkim Uniwersytetu Wrocławskiego i Uniwersytetu Ekonomicznego we Wrocławiu. Popularne w Polsce Wrocławskie Spotkania z Historia Gospodarcza zostały zainicjowane w 2005 r., a pierwsza konferencja została zorganizowana w roku kolejnym. W 2015 r. odbyło się na Dolnym Ślasku już 10. - jubileuszowe - spotkanie. Pokłosiem tych konferencji jest ogromny dorobek publikacyjny ${ }^{20}$. Liczba uczestników zjazdów historyków gospodarczych w ostatnich latach stale rosła, w 2014 r. wyniosła już 68, a w 2015 r. - 70.

Po trzecie, zapewniam, że stworzone zostały też nowe ramy instytucjonalne dla historyków gospodarczych. W wyniku integracji środowiska udało się w 2010 r. powołać do życia Polskie Towarzystwo Historii

19 Tamże.

${ }^{20}$ Zachęcam do przejrzenia spisów treści: http://www.wshg.wnhip.uni.wroc.pl/?type=publikacje, a także: http://gajt.pl/new/index.php?page=wroclawskie-spotkania-zhistoria-gospodarcza (14 VII 2014). 
Gospodarczej, które skupia nie tylko badaczy historii gospodarczej, ale miłośników historii sensu largo. Na stronie internetowej tej instytucji możemy przeczytać, że jego członkowie za cel stawiają sobie „rozwijanie i popularyzowanie wiedzy w zakresie historii gospodarczej, popieranie działań zmierzających do tego celu oraz wytwarzanie atmosfery szacunku do ogólnego i lokalnego dziedzictwa historyczno-gospodarczego" 21 . Pierwszy zjazd PTHG miał miejsce w Karpaczu w 2011 r. Fakty te chyba nie świadczą o kryzysie, przynajmniej nie o kryzysie instytucjonalnym.

Po czwarte, nie mam zamiaru wymieniać w tym miejscu plejady nazwisk badaczy, którzy kontynuuja pracę tak wybitnych postaci z polskiej historiografii jak Antoni Mączak, Jerzy Topolski czy Andrzej Wyczański. Pominięcie któregoś z wyróżniających się historyków gospodarczych byłoby nietaktem. Zapewniam jednak, że młodsze grono badaczy nie ma na ogół problemów ze znalezieniem przewodników naukowych w Polsce.

Po piąte, warto podkreślić, że zdecydowanie większą część grupy uprawiajacej dziś historię gospodarczą stanowią badacze tradycyjni, ale w najnowszych podręcznikach historii gospodarczej takich autorów jak Janusz Kaliński czy Janusz Skodlarski znajdziemy mnóstwo wykresów i tabel, co przeczy tezie o zamknięciu się historii na ilustrację statystyczna. Nie trzeba też bardzo się martwić o wykorzystywanie metod ilościowych przez młodszych specjalistów z historii gospodarczej (wywodzących się zarówno z historii, jak i ekonomii), o czym świadczą prace z bardzo różnych okresów dziejowych: od średniowiecza po transformację ustrojowa, takich autorów jak: Dariusz Grala ${ }^{22}$, Piotr Miodunka ${ }^{23}$, Janusz Myszczyszyn ${ }^{24}$ czy szczególnie, jako jedyny „czysty kliometryk” w tym gronie - przedstawiciel polskiej historii gospodarczej w cytowanych czasopismach zagranicznych - Jacek Wallusch ${ }^{25}$. Szkoda, że ten

${ }^{21} \mathrm{http}: / / \mathrm{www}$. pthg.pl/index.php?option=com_content\&view=article\&id=2\&Ite$\operatorname{mid}=107$ (14 VII 2014).

${ }^{22}$ D. Grala, Polskie przedsiębiorstwa przemysłowe na rynkach wschodnich $w$ latach 1990-2000, w: Z dziejów przemystu po 1945 roku, red. E. Kościk, R. Klementowski, Wrocław 2012, s. 309-326; zob. też: Przedsiębiorstwa podczas przemian systemowych $w$ Polsce przełomu XX i XXI wieku. Sukcesy i porażki na rynku, red. P. Czechanowski, D. Grala, Poznań 2013.

${ }^{23}$ P. Miodunka, Staropolskie księgi metrykalne jako źródto do badania klęsk elementarnych, w: Od powietrza, głodu, ognia i wojny... Klęski elementarne na przestrzeni wieków, red. T. Głowiński, E. Kościk, Wrocław 2013, s. 41-57.

${ }^{24}$ J. Myszczyszyn, Wptyw kolei żelaznych na wzrost gospodarczy Niemiec (1840 -1913), Łódź 2013.

${ }^{25}$ J. Streb, J. Wallusch, S. Yin, Knowledge Spill-Over From New to Old Industries. The Case of German Synthetic Dyes and Textiles (1878-1913), „Explorations in 
ostatni zawiesił ostatnio karierę uniwersytecka. Dzieli obecnie czas między pracę w założonym w 2013 r. Instytucie Kliometrii i Badań nad Transformacją ${ }^{26}$ a... trenowaniem zespołów futbolu amerykańskiego ${ }^{27}$.

Nie można zaprzeczyć, że historia gospodarcza miała trudne momenty w Polsce, ale nawet jeśli był to kryzys, to dziś nadchodzi ożywienie. Na pewno wychodzenie z recesji już nastapiło. Nie oznacza to oczywiście, że historia gospodarcza nie napotyka na problemy. Bardziej priorytetowe od doboru metod powinno być jednak przygotowanie historii gospodarczej do ogromu wyzwań związanych z wyborem nowych tematów, niezwykle ważnych społecznie i nośnych w dobie globalizacji. Tym bardziej że najnowsze przeglądy historiografii XX stulecia pokazuja, że „rosnace zwątpienie w możliwość »obiektywnej« historii nie doprowadziło do kresu badań historycznych ani do kresu historiografii, lecz do ich większego zróżnicowania"28. Autor tych słów - Georg Iggers - przekonuje, że historia jako nauka kryzysu nie przeżywa ${ }^{29}$. Takiego kryzysu nie dostrzegam też w przypadku historii gospodarczej ${ }^{30}$. Dominuje raczej przekonanie o istnieniu wielu historii, co ma znaczenie nie tylko dla rozwoju badań zwiąanych z mikrohistoria (od których historycy są silnie uzależnieni), ale też dla rozwoju makrohistorii (z której czerpią i którą badają zarówno historycy, jak ekonomiści).

Iggers twierdzi ponadto: „Jesteśmy nieustannie konfrontowani z procesami modernizacyjnymi na dużą skalę, z wszelkimi towarzyszącymi im zjawiskami społecznymi, technicznymi i kulturowymi, które zmuszają do pytań makrohistorycznych. [...] W ostatecznej instancji makrohistorii nie określa jej przedmiot, lecz pytania zadawane przez

Economic History” 2007, no. 44(2), s. 202-223; J. Wallusch, M. Baltzer, Inflation, Interest Rate and Innovations in Pre-WWI Germany (1878-1913), „Brussels Economic Review” 2009, no. 52(3/4). Polecam stronę internetowa Walluscha: http://www.wallusch-datenbank.de/clio.html.

${ }^{26}$ Zob. http://ikbt.org/beta.

${ }^{27}$ Wallusch jest uznawany za jednego z najbardziej doświadczonych trenerów tej dyscypliny. Trenował już zespoły z Wrocławia, Poznania i Warszawy. Posługiwanie się metodami ilościowymi pomaga mu $\mathrm{w}$ analizie taktycznej rywali, Wallusch słynie bowiem jako specjalista od gry defensywnej; więcej zob. Polska Liga Futbolu Amerykańskiego, w: Informator Prasowy, 2014, s. 13, http://plfa.pl/res/mce_res/2014/ InformatorPLFA2014.pdf.

${ }^{28}$ G.G. Iggers, Historiografia XX wieku. Przegląd kierunków badawczych, tłum. A. Gadzała, Warszawa 2010, s. 93.

${ }^{29}$ Tamże, s. 91.

${ }^{30}$ Zob. szerzej: R. Matera, Czy odwrót historii. Rozważania na temat miejsca historii $w$ nauce, w: $Z$ historii myśli ekonomicznej $i$ historii gospodarczej. Księga jubileuszowa prof. dr hab. Wiestawa Piątkowskiego, red. J. Skodlarski, Łódź 2006, s. 93-105. 
historyków”31. Gwoli ścisłości należy napisać, że wizja Iggersa odrzucająca „kres historii” nie pokrywa się z sądem innych ważnych historiografów XX w. Donald Kelley uważa na przykład, że historia w ubiegłym stuleciu doszła do końca cyklu rozwojowego, zatoczyła swoiste koło dziejów, wracając na pozycję z czasów starożytnej Grecji ${ }^{32}$.

W związku z powyższym nie powinniśmy zatem bać się w przyszłości podejmowania kwestii uznawanych dziś w Polsce za swoistą heterodoksję. Obok więc kontynuacji tradycyjnych studiów nad przemysłem, rolnictwem czy finansami powinniśmy zgłębiać obszary badawcze związane ze standardem życia, ewolucja systemowa, rozwojem/modernizacja/technologia. Przybliżajac się do tej wizji i korzystając także z metod i osiagnięć zachodniej historii gospodarczej, muszę powtórzyć postulat złożony w 2011 r. w Przegladzie badań nad historia gospodarcza $w$ XXI wieku, że potrzebna jest nie tylko współpraca historyków z ekonomistami, ale té̇ $\mathrm{z}$ archeologami, etnografami, geografami, prawnikami, politologami, socjologami (co się w Polsce na szczęście praktykuje coraz częściej), jak również z psychologami, biologami, lekarzami, inżynierami, a to by mogło mieć wymiar rewolucji naukowej ${ }^{33}$. To taką raczej perspektywę rozwoju należałoby kreślić.

\section{Bibliografia}

Di Vaio G., Weisdorf J., Ranking Economic History Journals. A Citation-Based Impact - Adjusted Analysis, „Discussion Papers” 2010, nr 9/11.

Eloranta J., Ojala J., Valtonen H., Are Business Historians Quantitatively Illiterate?, w: European Business History Association, Bergen 2008.

Godłów-Legiędź J., Wspótczesna ekonomia. Ku nowemu paradygmatowi?, Warszawa 2010.

Guzowski P., Poniat R., Miejsce badań kwantytatywnych we wspótczesnej historiografii polskiej, RGSG, t. 73, 2013.

Iggers G.G., Historiografia XX wieku. Przeglad kierunków badawczych, tłum. A. Gadzała, Warszawa 2010.

Kelley D.R., Granice historii. Badanie przeszłości w XX wieku, tłum. B. Hlebowicz, Warszawa 2009.

Matera R., Czy odwrót historii. Rozważania na temat miejsca historii w nauce, w: Z historii myśli ekonomicznej $i$ historii gospodarczej. Ksiega jubile-

${ }^{31}$ G. Iggers, dz. cyt., s. 92.

${ }^{32}$ Por. D.R. Kelley, Granice historii. Badanie przeszłości w XX wieku, tłum. B. Hlebowicz, Warszawa 2009.

${ }^{33}$ R. Matera, A. Pieczewski, Konkluzje, w: Przeglad badań nad historia gospodarczq..., s. 316. 
uszowa prof. dr. hab. Wiestawa Piatkowskiego, red. J. Skodlarski, Łódź 2006.

Przeglad badań nad historia gospodarcza $w$ XXI wieku, red. R. Matera, A. Pieczewski, Łódź 2011.

Snowdon B., Vane H.R., Rozmowy $z$ wybitnymi ekonomistami, tłum. M.A. Dabrowski, P. Kawa, Warszawa 2003.

Streb J., Wallusch J., Yin S., Knowledge Spill-Over From New to Old Industries. The Case of German Synthetic Dyes and Textiles (1878-1913), „Explorations in Economic History" 2007, nr 44(2).

\section{Rafał Matera}

Some remarks on the place of quantitative research in Polish economic history. The state and prospects

(Summary)

The article is a polemic on the text by Piotr Guzowski and Radosław Poniat entitled: The place of quantitative research in modern Polish historiography, which appeared in 2013 in the 73 volume of Roczniki Dziejów Spotecznych $i$ Gospodarczych [The Yearbook of Social and Economic History].

The article refers to a number of hypotheses and opinions presented by scholars who offered a critical analysis of the state of Polish economic history, the methods it uses and the scholarly potential it has. The article aims to present dilemmas faced by scholars specializing in economic history - one which rests on two pillars: history and economy. The author posits that economic history (not only in Poland), in exploring new ways of development, continues to rely both on a traditional history, known for its adherence to idiographic methods (which does not rule out the selection and juxtaposition of different data), and on contemporary economics, concerned mainly with model-building. The author argues for adopting a methodologically open approach to economic history, discussing a number of significant, both western and Polish, publications on this issue. The article also contains a review of the use of quantitative methods in Polish economic history.

Key words: quantitative methods, economic history 